\title{
PROSEDUR PEMBERIAN KREDIT DAN UPAYA UNTUK MENGATASI KREDIT MACET PADA KOPERASI KREDIT SWASTIASTU SINGARAJA
}

\author{
Birgita Gebiviona Allo \\ Jurusan Akuntansi Program Diploma III, \\ Universitas Pendidikan Ganesha, Singaraja \\ e-mail : gbirgita@yahoo.com
}

\begin{abstract}
Abstrak
Penelitian ini bertujuan untuk mengetahui prosedur pemberian kredit dan upaya untuk mengatasi kredit macet pada Koperasi Kredit Swastiastu Singaraja. Data yang digunakan yaitu data kualitatif berupa formulir-formulir kredit, pedoman perkreditan dan struktur organisasi Koperasi Kredit Swastiastu Singaraja dengan uraian tugasnya. Tehnik pengumpulan data yang digunakan adalah metode wawancara dan metode dokumentasi yang selanjutnya dianalisis dengan mengunakan analisis deskriptif kualitatif.

Hasil penelitian ini menunjukkan prosedur pemberian kredit yang diterapkan pada Koperasi Kredit Swastiastu Singaraja telah dilakukan dengan cukup baik oleh pihak koperasi dengan meliputi Bagian Kredit, Manajer, Bagian Kasir dan Bagian Accounting. Pada Bagian Kasir dibuatkan aplikasi pinjaman keluar berupa Bukti Pengeluaran Pinjaman, Bukti Kas Masuk (BKM), Bukti Kas Keluar (BKK). Dan pada Bagian Accounting melakukan pencatatan. Sebagai langkah awal tindak lanjut pihak koperasi dalam menangani kredit macet, dilakukan berbagai langkah yaitu : melakukan kunjungan secara kekeluargaan, dengan cara mendekati debitur, atau mendatangi rumahnya dan menanyakan permasalahan yang dihadapi, mengadakan pengawasan kepada debitur.
\end{abstract}

Kata Kunci : Prosedur Pemberian Kredit, Kredit Macet

\begin{abstract}
This study aims to find out the procedure of lending and attempt to get the bad loan over at Koperasi Kredit swastiastu Singaraja. The data used is qualitative data such as form for credit, credit guidelines and organizational structure of Koperasi Kredit Swastiastu Singaraja and the job descriptions. The Interviews method and the Description method are The Data Collection technique that being used and it continues analyzed by using descriptive and qualitative analysis.

The result of this study is showing the lending which applied at Koperasi Kredit Swastiastu Singaraja, it has been done quite well by Koperasi which is included the Credit department, the Manager, the Cashier, and the Accounting. The credit department has an assignment to do the survey to know the condition of the applicant. Then the manager will authorize for the loan approval. At the cashier department, they made an application system called proof of loan disbursement, evidence of incoming cash, evidence of outgoing cash. And at the accounting departement keeps it in record. As the first step follow-up of Koperasi in dealing with bad loan,done with a number of steps, such as: do visiting amicably, getting closer to debtors, or attend to their houses, ask the problem they faced, conduct surveilance to debtors, if the debtor does not execute the call from Koperasi, Koperasi will give I, II, III warning letter. But if debtors won't give a care for the warning letter. Koperasi will do confiscation of their goods.
\end{abstract}

Keywords : Procedure of lending, Bad loan 


\section{Pendahuluan}

Proses pemberian kredit merupakan kegiatan yang sangat kompleks, yang diperlukan dalam proses pemberian kredit adalah memahami lingkungan dimana perusahaan calon nasabah beroperasi, kecenderungan politik, ekonomi, teknologi dan sosial di Negara tempat nasabah beroperasi dapat mempengaruhi usahanya. Apalagi dengan prosedur pemberian kredit yang mudah dan cepat membuat para nasabah mudah untuk memperoleh modal untuk menjalankan bisnisnya. Salah satu ukuran keberhasilan suatu koperasi adalah apabila koperasi tersebut berhasil dalam pengelolaan kredit dalam usaha perkreditan akan dapat memberikan kontribusi pendapatan yang paling besar bagi usaha suatu koperasi didalam perekonomian. Jika prosedur pemberian kredit tidak dijalankan dengan baik maka kemungkinan akan menimbulkan kredit macet sehingga dapat mengurangi pendapatan atau penerimaan kas. Di dalam mengemban dan menjalankan perekonomian bangsa pemerintah telah berupaya untuk mendorong koperasi tumbuh dan berkembang. Disamping peraturan perundang-undangan yang dimaksudkan untuk mendorong pertumbuhan dan pengembangan koperasi. Koperasi sebagai badan usaha senantiasa harus diarahkan dan didorong untuk ikut berperan secara nyata meningkatkan pendapatan dan kesejahteraan, agar mampu mengatasi ketimpangan ekonomi dan kesenjangan sosial, sehingga lebih mampu berperan sebagai wadah kegiatan ekonomi rakyat.

Berdasarkan Undang-Undang No.25 tahun 1992 pasal 1 ayat 1 tentang perkoperasian, disebutkan bahwa koperasi adalah badan usaha yang beranggotakan orang-orang atau badan hukum koperasi dengan melandaskan kegiatannya berdasarkan prinsip koperasi sekaligus sebagai gerakan ekonomi rakyat yang berdasarkan asas kekeluargaan. Sebagai salah satu pelaku ekonomi, koperasi merupakan organisasi ekonomi yang berusaha menggerakkan potensi sumber daya ekonomi demi memajukan kesejahteraan anggota. Karena sumber daya ekonomi terbatas, dan dalam mengembangkan koperasi harus mengutamakan kepentingan anggota, maka koperasi harus mampu bekerja seefisien mungkin dan mengikuti prinsip-prinsip koperasi dan kaidah-kaidah ekonomi.

Dalam perkembangan koperasi di Indonesia yang cukup pesat dewasa ini, salah satu koperasi yang sering kita jumpai adalah koperasi jenis simpan pinjam. Tidaklah mudah untuk menjaga dan mempertahankan kelangsungan keberadaan koperasi tersebut. Untuk mempertahankan hal tersebut koperasi haruslah pandai-pandai mengolah sumber dana atau modal yang tersedia untuk menghasilkan keuntungan yang maksimal. Dalam kaitannya dengan koperasi simpan pinjam fungsi yang sama juga berlaku, koperasi menghimpun dana melalui simpanan pokok, simpanan wajib dan berupa jasa simpanan (tabungan) kemudian menyalurkan dana tersebut melalui kredit-kredit yang diberikan.

Koperasi Kredit Swastiastu Singaraja yang didirikan oleh para Guru dan Karyawan Yayasan Insan Mandiri pada tanggal 1 September 1981 memiliki tiga pilar yaitu pendidikan, solidaritas, dan swadaya. Prosedur pemberian kredit yang diberikan oleh Koperasi Kredit Swastiastu Singaraja sama halnya dengan koperasi-koperasi lain tetapi Koperasi Kredit Swastiastu Singaraja hanya memberikan kredit kepada nasabah yang sudah menjadi anggota Koperasi saja. Selain itu calon nasabah juga harus memberikan jaminan dalam mengajukan kredit misalnya seperti BPKB motor atau mobil.

Dalam penyaluran kredit-kredit tersebut koperasi sebenarnya mempunyai resiko yang cukup besar, yaitu bisa terjadi adanya kredit bermasalah. Saat ini Koperasi Kredit Swastiastu Singaraja masih banyak menangani kredit macet/bermasalah yang mesti harus ditangani secara intensif yaitu pada pinjaman dibawah $\mathrm{Rp} 1.000 .000,00$. Kredit ini harus menjadi perhatian khusus bagi pihak koperasi karena kredit ini yang paling banyak mengalami kredit macet yang nantinya bisa merugikan pihak koperasi. Dalam mengatasi kredit macet, koperasi Kredit Swastiastu Singaraja berpegang teguh pada asas kekeluargaan, sehingga dalam menyelesaikan kredit bermasalah ini diusahakan secara damai, kekeluargaan, dalam pihak 
koperasi agar nantinya para nasabah nyaman bila mengajukan kredit lagi. Apalagi nasabahnasabah Koperasi Kredit Swastiastu adalah anggota-anggota koperasi.

\section{Metode Penelitian}

Tujuan yang ingin dicapai dari penelitian ini adalah untuk mengetahui prosedur pemberian kredit yang telah diterapkan oleh Koperasi Kredit Swastiastu Singaraja dan untuk mengevaluasi prosedur pemberian kredit dan upaya mengatasi kredit macet pada Koperasi Kredit Swastiastu Singaraja. Pada Penelitian ini, data yang dipergunakan adalah data kualitatif yang merupakan focus utama dari tujuan penelitian. Agar tujuan peneliti dapat tercapai, maka peneliti melakukan kumpulan data dengan metode wawancara yaitu pengumpulan data dengan cara mengadakan tanya jawab secara langsung dengan pihak-pihak yang bersangkutan pada Koperasi Kredit Swastiastu Singaraja untuk mendapatkan informasi yang lebih jelas observasi pengumpulan data ini adalah dengan pengamatan secara langsung terhadap objek yang diamati dengan melihat dan menghimpun data yang berkaitan dengan prosedur pemberian kredit dan upaya untuk mengatasi kredit macet pada Koperasi Kredit Swastiastu pada Koperasi Kredit Swastiastu Singaraja, dan dokumentasi yaitu pengumpulan data dengan cara mempelajari dan memahami data-data atau catatan-catatan yang berkaitan dengan prosedur pemberian kredit dan upaya untuk mengatasi kredit macet pada Koperasi Kredit Swastiastu Singaraja. Data yang telah terkumpul akan dianalisis dengan analisis deskriptif kualitatif. Analisis deskriptif kualitatif adalah analisis yang tidak menggunakan perhitungan statistical dan dilakukan dengan cara membaca data yang telah diolah yang pada dasarnya analisis ini menggunakan penelitian logis, analisis dengan logika. Metode ini menguraikan atau menggambarkan, memaparkan dan menjelaskan segala informasi mengenai prosedur pemberian kredit dan upaya mengatasi kredit macet pada Koperasi Kredit Swastiatu Singaraja. Metode deskriptif kualitatif ini menggambarkan bagaimana keadaan yang ada mengenai data yang berhubungan dengan prosedur pemberian kredit dan upaya untuk mengatasi kredit macet pada Koperasi Kredit Swastiastu Singaraja.

\section{Hasil dan Pembahasan}

\section{a. Prosedur Pemberian Kredit pada Koperasi}

Langkah-langkah yang harus dilaksanakan dalam pelaksanaan pemberian kredit yaitu : Permohonan kredit diajukan oleh pemohon kredit kepada koperasi, permohonan ini disampaikan kepada manager, dan oleh manager diteruskan di bagian kredit untuk diolah oleh bagian kredit, permohonan ini diserahkan pada seksi analisa untuk dilakukan penelahaan. Apabila data untuk mempertimbangkan cukup maka analisis terus dapat dilakukan, tetapi bila masih memerlukan data seksi analisis dapat meminta tambahan keterangan kepada nasabah bersangkutan. Setelah di analisis maka diperiksa oleh kepala bagian kredit dan di susunlah analisis dan mengambil keputusan diteruskan ke bagian kredit untuk dilaksanakan. Persiapan perjanjian kredit di urus oleh seksi analisis dan setelah itu diparaf oleh Kepala Seksi Pemberian Kredit. Pemberian kredit di tandatangani oleh nasabah dan direktur pengawasan dan pengamanan atas fasilitas kredit yang diberikan koperasi dilakukan sampai kredit itu lunas.

Antara prosedur dan proses dalam hal pemberian kredit memiliki keterkaitan, yang mana prosedur menyangkut personalia atau bagian-bagian yang terkait dengan pemberian kredit, sedangkan proses menyangkut alur dari dokumen permohonan kredit yang diajukan oleh calon debitur. Setelah akad kredit ditandatangani maka langkah selanjutnya adalah merealisasi kredit. Realisasi kredit diberikan setelah penandatanganan surat-surat yang diperlukan dengan membuka tabungan di koperasi yang bersangkutan. Dengan demikian penarikan dana kredit dapat dilakukan melalui tabungan tersebut. Pencairan atau pengambilan uang dari tabungan sebagai realisasi dari pemberian kredit dapat diambil sesuai ketentuan dan tujuan tertentu.

Upaya untuk mengatasi kredit macet

\section{Rescheduling}


Rescheduling adalah penjadwalan kembali sebagian atau seluruh kewajiban debitur dengan memperpanjang jangka waktu kredit/angsuran. Dalam hal ini si debitur diberikan keringanan dalam masalah jangka waktu kredit pembayaran kredit, misalnya perpanjangan jangka waktu kredit dari 6 bulan menjadi satu tahun sehingga si debitur mempunyai waktu yang lebih lama untuk mengembalikannya.

2. Reconditioning

Reconditioning merupakan usaha pihak bank untuk menyelamatan kredit yang diberikannya dengan cara mengubah sebagaian atau seluruh kondisi (persyaratan) yang ada seperti : kapasitas bunga, penundaan pembayaran bunga sampai waktu tertentu, penurunan suku bunga, dan pembebasan bunga.

3. Restructuring

Restructuring merupakan tindakan bank kepada nasabah dengan cara menambah modal nasabah dengan pertimbangan nasabah memang membutuhkan tambahan dana dan usaha yang dibiayai memang layak. Tindakan ini meliputi, dengan menambah jumlah kredit, dan dengan menambah equity.

4. Kombinasi 3-R

Kombinasi 3-R merrupakan tindakan bank kepada nasabah dengan kombinasi antara rescheduling, reconditioning, dan restructuri

\section{b. Prosedur Pemberian Kredit pada Koperasi Kredit Swastiastu Singaraja}

Prosedur pemberian kredit pada Koperasi Kredit Swastiastu Singaraja diawali dengan kedatangan calon debitur ke bagian kredit untuk meminta formulir surat permohonan pinjaman dan diisi dengan syarat yang telah ditentukan. Syarat-syarat meminjam yaitu pemohon harus sudah menjadi anggota Koperasi Kredit Swastiastu Singaraja, menyerahkan jaminan yaitu BPKB atau sertifikat tanah dan bangunan masing-masing satu lembar, fotokopi KTP pemohon satu lembar, fotokopi pemilik BPKB satu lembar, materai Rp. 6.000,00 satu lembar. Dan untuk peminjam yang meminjam di atas Rp. 10.000.0000,00 merupakan peminjam jangka panjang, harus menyerahkan anggunan sertifikat tanah atau bangunan yaitu Kredit Menunjang Prestasi dan Kredit Investasi Produktif. Setelah itu manajer melakukan survey ke lokasi/tempat calon debitur tinggal, disana manajer akan melakukan survey tentang usaha yang dijalankan oleh calon debitur serta kesanggupan calon debitur dalam melunasi utangnya. Survey ini bertujuan untuk mengetahui apakah benar calon debitur ingin benar-benar memanfaatkan pinjaman tersebut dan manajer juga ingin mengetahui apakah calon debitur benar- benar memiliki jaminan yang dilampirkan serta manajer akan mempertimbangkan pinjamannya dengan jaminan tersebut. Kemudian dibagian kredit akan mengumpulkan data, menilai jaminan, dan menganalisis permohonan pinjaman tersebut serta hasil survey yang dibuat oleh bagian kredit manajer.

Setelah permohonan disetujui oleh bagian kredit maka dibuatkan Surat Perjanjian Pinjaman, Surat Kuasa, dan Surat Pernyataan masing rangkap dua. Selain surat-surat tersebut, oleh bagian kredit dibuatkan kitir pinjaman dua lembar berwarna kuning. Setelah itu surat-surat tersebut dibawa ke manajer untuk diotorisasi. Setelah itu maka lembar pertama akan dibawa oleh peminjam dan lembar kedua disimpan oleh bagian kredit sebagai arsip.

Setelah Surat Perjanjian Pinjaman, Surat Kuasa, dan Surat Pernyataan diotorisasi oleh manajer, surat-surat tersebut juga harus diotorisasi oleh peminjam. Kemudian peminjam akan membawa surat-surat tersebut ke bagian kasir untuk dibuatkan Bukti Pengeluaran Kas, Bukti Kas Masuk (BKM), Bukti Kas Keluar (BKK), serta dilanjutkan dengan penyerahan uang kepada penerima pinjaman, serta dipotong biaya administrasi $1 \%$ dan cadangan khusus $1 \%$ dari pinjaman. Untuk pinjaman dibawah Rp 1.000.000,00 peminjam yang tabungannya sudah melebihi Rp 1.000.000,00 tidak perlu menyerahkan jaminan karena tabungan tersebut akan menjadi jaminan sedangkan peminjam yang tabungannya dibawah Rp 1.000.000,00 harus menyertakan jaminan dan peminjam diatas $\mathrm{Rp}$. 10.000.000,00 penyelesainnya dilakukan 
dikantor notaris yang ditunjuk. Setelah kredit dicairkan bagian kredit akan menyerahkan bukti kas masuk, bukti kas keluar, bukti pengeluaran pinjaman ke bagian accounting. Bagian accounting akan mencatat transaksi yang timbul dari bukti kas masuk, bukti kas keluar, dan bukti pengeluaran pinjaman untuk selanjutnya dibuatkan jurnal sampai dengan laporan keuangan.

\section{c. Upaya untuk Mengatasi Kredit Macet pada Koperasi kredit Swastiastu}

Tindakan yang dilakukan untuk mengatasi kredit macet oleh Koperasi Kredit Swastiastu Singaraja adalah sebagai berikut,

1. Melakukan kunjungan secara kekeluargaan.

Hal ini dapat dilakukan dengan cara mendekati debitur atau mendatangi rumahnya dan menanyakan permasalahan yang dihadapi nasabah tersebut sehingga tidak melaksanakan kewajibannya.

2. Mengadakan pengawasan kepada debitur

Pengawasan ini dilaksanakan oleh bagian kredit Koperasi Kredit Swastiastu Singaraja dengan jadwal tergantung kapan nasabah menunjukkan gejala-gejala bermasalah. Jadi jadwal pengawasan kepada debitur tidak teratur. Langkah ini dilakukan kepada semua debitur yang mengalami masalah dalam pencairan kredit. Cara ini hampir sama dengan cara penagihan intensif yaitu terhadap anggota/debitur yang usahanya masih berprospek dan dianggap masih mempunyai itikad baik, namun telah menunjukkan gejala-gejala kearah kredit bermasalah harus dilakukan penagihan insentif kepada anggota/debitur agar memenuhi kewajibannya.

a) Memberikan Surat Peringatan I

Dalam hal ini Surat Peringatan I yaitu tentang kewajiaan debitur untuk melaksanakan kewajibannya membayar tunggakkan yang belum dibayar dengan memberikan jangka waktu paling lambat 35 hari setelah Surat Peringatan I diberikan oleh pihak Koperasi.

b) Memberikan Surat Peringatan II

Dalam hal ini Surat Peringatan II masih membahas tunggakan Administrasi belum dibayar. Surat Peringatan II akan diberikan jika dalam 35 hari debitur belum melaksanakan kewajibannya setelah Surat Peringatan I diberikan.

c) Memberikan Surat Peringatan III

Dalam hal ini Surat Peringatan III merupakan Surat peringatan terakhir yang diberikan oleh pihak koperasi kepada debitur. Surat Peringatan III juga diberikan kepada debitur jika dalam 35 hari debitur juga belum melaksanakan kewajibannya setelah Surat Peringatan II diberikan. Dan apabila dalam jangka waktu yang ditentukan debitur tidak melunasi kewajibannya maka akan diselesaikan dengan jalur hukum yang berlaku melalui Badan Urusan Piutang dan Lelang Negara (BUPLN).

d) Sita Jaminan

Dalam hal ini dilakukan penyitaan terhadap barang jaminan melalui BUPLN dan jaminan debitur akan digunakan untuk menutupi sisa tunggakan yang belum dilunasi. Apabila ada sisa dari pelelangan tersebut maka akan dikembalikan oleh debitur.

\section{Simpulan dan Saran}

Prosedur pemberian kredit pada Koperasi Kredit Swastiastu Singaraja diawali dengan kedatangan calon debitur ke bagian kredit untuk meminta formulir surat permohonan pinjaman dan diisi dengan syarat yang telah ditentukan. Kemudian bagian manajer akan melakukan survey ke lokasi calon debitur untuk mengetahui usaha yang dijalankan oleh calon debitur dan mengetahui apakah calon debitur tersebut sanggup dalam melunasi kewajibannya. Bagian kredit akan mengumpulkan data, menilai jaminan dan menganalisis permohonan pinjaman tersebut. Kemudian peminjam akan membawa surat-surat tersebut ke bagian kasir untuk dibuatkan Bukti Pengeluaran Kas, Bukti Kas Masuk (BKM), Bukti Kas Keluar (BKK), serta 
dilanjutkan dengan penyerahan uang kepada penerima pinjaman. Bagian accounting akan mencatat transaksi yang timbul dari bukti kas masuk, bukti kas keluar, dan bukti pengeluaran pinjaman untuk selanjutnya dibuatkan jurnal sampai dengan laporan keuangan.

Sebagai langkah awal tindak lanjut pihak koperasi dalam menangani kredit macet tersebut, dilakukan berbagai langkah yaitu : melakukan kunjungan secara kekeluargaan, dengan cara mendekati debitur, atau mendatangi rumahnya dan menanyakan permasalahan yang dihadapi, mengadakan pengawasan kepada debitur yang dilaksanakan oleh bagian kredit dengan jadwal tergantung kapan debitur menampakan gejala-gejala bermasalah sehingga jadwal pengawasan terhadap debitur tidak diatur secara pasti karena tenggang waktu kredit dari masing-masing debitur tidak sama. Apabila debitur tidak melaksanakan himbauan dari pihak koperasi, maka pihak koperasi akan memberikan Surat Peringatan I,II,III. Setelah diberikan Surat Peringatan tersebut, namun debitur tidak menghiraukan maka pihak koperasi akan melaksanakan penyitaan barang jamiman.

\section{Daftar Pustaka}

Dendawijaya. 2005. Kredit Bermasalah. : http://www.repository.upi.ac.id

Kasmir. 2007. Tentang upaya untuk mengatasi kredit macet : http://id.shvoong.com/business-management/marketing

Mudrajad Kuncoro. 2002. : Kredit bermasalah/macet. http://www.petra.ac.id/

Prabowo, Hendro, dkk. 2005. Ekonomi. Jakarta : Fakultas Ekonomi Universitas Indonesia. 